\title{
PENGARUH PENAMBAHAN ARANG AKTIF TERHADAP MUTU SABUN MANDI CAIR RUMPUT LAUT (Gracilaria sp.)
}

\author{
THE EFFECT OF ADDITION ACTIVE CHARCOAL TO THE QUALITY OF SEAWEED \\ SHOWER SOAP (Gracilaria sp.)
}

\section{Anasri Tanjung, Sukma B. Prasetyati*, Ade Kusuma Wardani, dan Rahmat Surya Hadi Saputra}

Politeknik Kelautan dan Perikanan Karawang, Jalan Lingkar Tanjungpura, Karangpawitan, Kecamatan Karawang Barat, Kabupaten Karawang, Jawa Barat 41315

Teregistrasi I tanggal: 09 Oktober 2019; Diterima setelah perbaikan tanggal: 28 Desember 2019; Disetujui terbit tanggal: 24 Januari 2020

\begin{abstract}
ABSTRAK
Sabun merupakan molekul organik yang terdiri dari dua gugus yaitu gugus polar dan non polar. Formulasi penambahan arang aktif pada sabun mandi cair dipercaya dapat menyerap dan mengangkat kotoran dari permukaan sampai ke dalam pori-pori. Penelitian ini bertujuan untuk memformulasikan pembuatan sabun mandi cair rumput laut dengan penambahan arang aktif, serta melakukan pengujian mutu sabun mandi cair rumput laut yang meliputi pengujian organoleptik, $\mathrm{pH}$, kadar logam merkuri, viskositas dan stabilitas busa. Penelitian dilakukan dari tanggal 11 Maret 2019 sampai dengan 29 Juni 2019 di PT. Rumah Rumput Laut Bogor, dengan bahan baku rumput laut diambil dari Kabupaten Karawang. Penelitian ini menggunakan perlakuan penambahan dan tanpa penambahan arang aktif. Data yang diperoleh kemudian diolah menggunakan statistik untuk mencari nilai rata-rata. Formulasi bahan dalam pembuatan sabun mandi cair rumput laut adalah TEA dan setil alkohol $2.08 \%$, EDTA, sodium klorida dan penoxyetanol $0.98 \%$, gliserin dan VCO $3,47 \%$, esensial oil $0.58 \%$, bubur $23.16 \%$, asam sitrat dan arang aktif $2.32 \%$, aquades $50.96 \%, \mathrm{KOH}$ $1.97 \%$ dan minyak jarak $4.63 \%$. Pengujian mutu yang dilakukan pada sabun mandi cair rumput laut pada laboratorium dengan penambahan arang aktif adalah $\mathrm{pH}$ sebesar 9.44, tidak ditemukannya logam merkuri, viskositas sebesar $424 \mathrm{cPs}$, stabilitas busa sebesar $78.95 \%$ dan nilai kesukaan terhadap warna, aroma, kekentalan, jumlah busa, kesan licin, kesan lembut yang ditinggalkan sebesar 6 (suka) dari skala 1 sampai dengan 7.
\end{abstract}

Kata kunci: arang aktif, sabun cair dan rumput laut (Gracilaria sp)

\begin{abstract}
Soap is an organic molecule consisting of two groups namely polar and non-polar groups. The formula for adding activated charcoal to liquid bath soap is believed to absorb and remove impurities from the surface to the pores. This research aims to formulate the manufacture of seaweed shower soap with added active charcoal, and to quality assessment of seaweed shower soap which includes testing of organoleptic, $\mathrm{pH}$, mercury, viscosity and foam stability. This research was done form 11 march - 29 june 2019 at PT. Rumah Rumput Laut Bogor. Raw material was taken from Karawang Regency. The research used treatment with and without addition of charcoal. The data obtained were processed statistically using the results of quality. The ingredients of shower foam are TEA and cetyl alcohol 2.08\%, EDTA, sodium chloride and penoxyetanol $0.98 \%$, gliserin and VCO 3,47\%, essential oil $0.58 \%$, seaweed porridge $23.16 \%$, citric acid and activated charcoal $2.32 \%$, aquades $50.96 \%, \mathrm{KOH} 1.97 \%$ and castor oil $4.63 \%$. Assessment conducted on seaweed liquid shower soap in the laboratory with the addition of
\end{abstract}

Korespondensi penulis:

*Email: sukmabudiprasetyati@gmail.com

DOI: http://dx.doi.org/10.15578/plgc.v1i1.8651 
activated charcoal were a pH of 9.44, no mercury was found, viscosity of 424 cps, foam stability of $78.95 \%$ and for value of fondness for color, aroma, thickness, amount of shower soap, slippery impression, soft impression were 6th level (liking) on the 1 to 7 scale.

Keywords: activated charcoal, shower soap and seaweed (gracilaria sp)

\section{PENDAHULUAN}

Sabun merupakan molekul organik yang terdiri dari dua gugus yaitu gugus polar dan non polar. Gugus non polar adalah gugus bersifat hidrofobik sehingga dapat mengikat kotoran (lemak) pada kulit. Sedangkan gugus polar adalah gugus yang bersifat hidrofilik atau suka air sehingga ketika dibilas maka kotoran akan terikat bersama air bilasan (Salam, 2003). Pada umumnya, sabun terdiri dari dua komponen utama yaitu asam lemak dengan rantai karbon $\mathrm{RCOOH}$ dan Sodium atau Potasium. Proses pembuatan sabun disebut saponifikasi. Proses saponifikasi minyak akan diperoleh produk sampingan yaitu gliserol dan terjadi karena reaksi antara trigliserida dengan alkali (Suryakusuma, 2006).

Sabun cair adalah sediaan berbentuk cair yang ditujukan untuk membersihkan kulit, dibuat dari bahan dasar sabun yang ditambahkan surfaktan, pengawet, penstabil busa, pewangi dan pewarna yang diperbolehkan, dan dapat digunakan untuk mandi tanpa menimbulkan iritasi pada kulit (SNI, 1996). Sabun cair memiliki bentuk yang menarik dan lebih praktis dibandingkan sabun dalam bentuk padatan. Sabun antiseptik yang beredar di pasaran apabila sering digunakan dalam rentang waktu yang lama dapat menyebabkan efek samping dan iritasi kulit (Sharma et al., 2016).

Rumput laut memiliki berbagai manfaat yang sangat beragam terutama bagi dunia industri. Hal ini karena adanya kandungan alginat, agar-agar, karagenan, dan zat-zat lain yang juga sangat kaya dengan mineral. Industri yang telah memanfaatkan rumput laut antara lain pada industri makanan, kosmetik, farmasi, tekstil, dan food suplement
(Astawan, 2004). Beberapa jenis rumput laut yang terdapat di Indonesia dan memiliki arti ekonomis penting adalah:

1) Rumput laut penghasil agar-agar (Agarophyte), yaitu Gracilaria, Gelidium, Gelidiopsis, dan Hypnea;

2) Rumput laut penghasil karaginan (Canagenophyte), yaitu Eucheuma spinosum, Eucheuma cottonii, Eucheuma striatum; dan

3) Rumput laut penghasil algin (Alginophyte), yaitu Sargasum, Macrocystis, dan Lessonia (Astawan, 2004).

Agar-agar merupakan ekstrak dari rumput laut yang salah satunya berasal dari jenis Gracilaria sp, sedangkan Gracilaria sendiri merupakan rumput laut yang termasuk dalam golongan Rhodophyceae (alga merah). Masyarakat pesisir di Indonesia mengenal Gracilaria sp dengan sebutan; janggut dayung (Bangka); agar-agar kerang (Indonesia); sango-sango, dongi-dongi (Sulawesi); bulung embung (Jawa, Bali); bulung sangu (Bali); bulung tombong putih (Labuhanhaji, Lombok). Dalam kehidupan sehari-hari, agar-agar dimanfaatkan sebagai bahan makanan seperti puding, menjadi jelly (makanan ringan) dan sebagainya. Sedangkan dalam industri, agar-agar digunakan sebagai bahan tambahan pada pabrik pengalengan makanan, farmasi, kosmetik, cat tekstil dan lain-lain. Gracilaria sp mempunyai komposisi kimia yang dapat dilihat pada Tabel 1 .

Arang merupakan produk dari proses karbonisasi kayu yang sebagian besar komponennya merupakan karbon. Arang aktif sendiri merupakan arang yang telah mengalami pemprosesan secara lanjut dengan pemanasan tinggi atau dengan menggunakan bahan-bahan kimia sehingga pori-pori yang dimiliki 
arang menjadi terbuka dan mampu menjadi absorben. Daya serap arang aktif terjadi karena adanya pori-pori berukuran

Tabel 1. Komposisi kimia Rumput Laut Gracilaria sp dalam 100 gram kering Table 1. Chemical composition of Gracilaria sp. Seaweed in 100 grams of dried

\begin{tabular}{ccr}
\hline No & Parameter & Kandungan \\
\hline 1 & Kalori (kkal) & 312 \\
2 & Protein $(\mathrm{g})$ & 1,3 \\
3 & Lemak (g) & 1,2 \\
4 & Karbohidrat $(\mathrm{g})$ & 83,5 \\
5 & Serat $(\mathrm{g})$ & 2,7 \\
6 & Abu $(\mathrm{g})$ & 4 \\
7 & Kalsium $(\mathrm{mg})$ & 756,0 \\
8 & Fosfor $(\mathrm{mg})$ & 18 \\
9 & Besi $(\mathrm{mg})$ & 7,8 \\
10 & Natrium $(\mathrm{mg})$ & 115,0 \\
11 & Kalium $(\mathrm{mg})$ & 107,0 \\
12 & Thiamin $(\mathrm{mg})$ & 0,01 \\
13 & Riboflamin $(\mathrm{mg})$ & 0,22 \\
14 & Niasin $(\mathrm{mg})$ & 0,2 \\
\hline
\end{tabular}

Sumber: Suhartono (2000)

Pemanfaatan arang aktif sebagai absorben banyak digunakan untuk menyerap cairan beracun, gas beracun, bau busuk, penjernih air, dan sebagainya (Akhmad, 2012). Bahan baku yang dapat digunakan sebagai pembuatan arang aktif antara lain adalah limbah serbuk gergaji, limbah potongan-potongan kayu, limbah industri perkebunan kelapa sawit, tempurung kelapa, tanaman kayu hutan, aspal muda, dan lain-lain (Siddiq, 2015).

Menurut Lempang (2014), arang aktif dapat dibedakan dengan arang berdasarkan sifat pada permukaannya. Permukaan arang masih ditutupi deposit hidrokarbon yang menghambat keaktifannya, sedangkan permukaan arang aktif relatif lebih bebas dari deposit, permukaannya luas dan pori-porinya telah terbuka sehingga memiliki daya serap tinggi. Untuk meningkatkan daya serap arang maka bahan tersebut dapat diubah menjadi arang aktif melalui proses kativasi. Formulasi penambahan arang aktif pada sabun mandi cair dipercaya dapat menyerap dan mengangkat kotoran dari permukaan sampai ke dalam poripori. mikro yang jumlahnya banyak (Yustinah, 2011).

\section{BAHAN DAN METODE Bahan}

Bahan-bahan yang digunakan untuk pembuatan bubur antara lain: rumput laut Gracilaria sp yang diambil dari daerah Karawang, air, kertas $\mathrm{pH}$ dan larutan kaporit $0,25 \%$. Bahan-bahan yang digunakan untuk proses pembuatan sabun mandi cair antara lain: bubur rumput laut Gracilaria sp, arang aktif, aquades, TEA, VCO, minyak jarak, penoxyetanol, setil alkohol, asam sitrat, EDTA, $\mathrm{NaCl}, \mathrm{KOH}$, gliserin. Sedangkan bahan-bahan yang digunakan untuk analisis sabun mandi cair antara lain: aquades, contoh sabun mandi cair, propilen glikol, gliserin, larutan pengencer, asam nitrat, larutan baku.

\section{Analisis Data}

Proses penelitian dilakukan dengan cara mengambil data secara langsung pada saat proses pembuatan sabun mandi cair, dan dilakukan pengujian di laboratorium. Beberapa pengujian yang dilakukan adalah sebagai berikut:

a. Uji Sensori

Uji sensori dilakukan oleh panelis agak terlatih sebanyak 25 orang. Panelis diminta untuk menilai kekentalan, aroma, jumlah busa yang dihasilkan oleh sabun mandi cair, warna, dan kesan licin, kesan lembut (kelembutan) yang ditinggalkan pada kulit. Hal ini dilakukan berdasarkan uji hedonik untuk mengetahui tingkat kesukaan panelis. Menurut Rahayu (1998) pengujian ini menggunakan 7 skala kesukaan yaitu: 1 (sangat tidak suka), 2 (tidak suka), 3 (agak tidak suka), 4 (biasa), 5 (agak suka), 6 (suka), dan 7 (sangat suka).

b. Uji derajat keasaman $(\mathrm{pH})$

Analisis kimia yang dilakukan terhadap sabun mandi cair berdasarkan SNI: 06-4085-1996 
berupa derajat keasaman $(\mathrm{pH})$. Alat $\mathrm{pH}$-meter dikalibrasi terlebih dahulu dengan larutan buffer $\mathrm{pH} 6.86$ ketika akan melakukan pengukuran. Elektroda yang telah dibersihkan dicelupkan dengan air suling. Pengukuran dilakukan dengan mencelupkan elektroda ke dalam contoh yang akan diperiksa pada suhu $25^{\circ} \mathrm{C}$ (Deiner, 2008).

c. Uji Logam Merkuri

Analisis kimia yang dilakukan selanjutnya yaitu melihat kandungan merkuri. Sampel ditimbang dan ditambahkan $\mathrm{HNO}_{3}$ dan $\mathrm{H}_{2} \mathrm{SO}_{4}$ dengan diaduk sampai merata. Panaskan sekitar 3 jam kemudian tambahkan $\mathrm{H}_{2} \mathrm{O}_{2}$ dan dinginkan. Masukkan ke dalam botol kaca. Sehari kemudian larutan sampel disaring dengan kertas saring. Pengukuran kadar logam merkuri dengan menggunakan SSA.

d. Uji Viskositas

Viskositas merupakan salah satu analisis yang dapat menunjukkan sifat fisik dari suatu produk. Selain itu viskositas juga dapat menunjukkan kestabilan produk. Nilai viskositas untuk produk sabun mandi cair umumnya berkisar antara 400-4000 cPs (Williams dan Schmitt, 2002). Pengukuran viskositas dilakukan dengan menggunakan viskometer brookfield (viskometer yang bekerja dengan cara menggerakkan suatu benda di dalam cairan dengan cara membiarkan bola jatuh). Sampel sebanyak $30 \mathrm{ml}$ dituangkan ke dalam suatu wadah dan diukur viskositasnya menggunakan spindle no. 3 dan no. 4 dengan kecepatan pengadukan 30 rpm. Viskositasnya (cPs) adalah faktor koreksi (40 untuk spindle no.3 dan 200 spindle no.4) dikalikan dengan angka hasil pengukuran.

e. Uji Stabilitas Busa

Aquades dan sabun mandi cair dengan perbandingan 9:1 dimasukkan ke dalam tabung reaksi. Tabung reaksi yang telah berisi larutan tersebut diletakkan diatas vortex untuk dilakukan pemutaran. Pemutaran dilakukan selama 5 menit, setelah pemutaran, dihitung tinggi busa yang terdapat di dalam tabung reaksi $(\mathrm{a} \mathrm{cm})$. Lalu didiamkan tabung reaksi selama satu jam, kemudian hitung kembali tinggi busa yang masih tertinggal di dalam tabung reaksi (b cm) sesuai Pers. (1) (Deiner, 2008).

Stabilitas Busa $=\frac{b}{a} \times 100 \%$

\section{HASIL DAN BAHASAN HASIL \\ Formulasi Bahan}

Hasil formulasi bahan pembuatan sabun mandi cair rumput laut dengan penambahan arang aktif dapat dilihat pada Tabel 2.

\section{Pengujian Sabun Rumput Laut}

Hasil pengujian sabun mandi cair rumput laut dapat dilihat pada Tabel 3. Pengukuran derajat keasaman dilakukan pada saat proses pembuatan sabun rumput laut yang dilakukan di PT. Saraswati Indo Genetech dengan hasil sesuai Gambar 1.

Logam merkuri $(\mathrm{Hg})$ termasuk logam berbahaya yang dalam konsentrasi kecil pun dapat bersifat racun. Pemakaian merkuri dapat menimbulkan efek samping, antara lain iritasi kulit, kulit menjadi merah, dan rasa terbakar. Hasil pengujian sabun cair rumput laut pada PT. Saraswati Indo Genetech menunjukkan bahwa "tidak ditemukan (not detected)" logam merkuri di bahan baku maupun bahan tambahan. Hasil pengujian kandungan logam merkuri pada sabun cair rumput laut dapat dilihat pada Tabel 4. 
PELAGICUS: Jurnal IPTEK Terapan Perikanan dan Kelautan

Vol.1 No.1: 31-38, Januari 2020

Tabel 2. Formulasi bahan

Table 2. Ingredients formulation

\begin{tabular}{lcc}
\hline \multirow{1}{*}{ Bahan } & \multicolumn{2}{c}{ Konsentrasi (\%) } \\
\cline { 2 - 3 } & $0 \%$ & $2 \%$ \\
\hline TEA & 2.13 & 2.08 \\
EDTA & 1.01 & 0.98 \\
Gliserin & 3.56 & 3.47 \\
Sodium Klorin & 1.01 & 0.98 \\
Esensial Oil & 0.59 & 0.58 \\
Bubur & 23.71 & 23.16 \\
Asam Sitrat & 2.37 & 2.32 \\
Aquades & 52.16 & 50.96 \\
Pottasium Hydroxide & 2.01 & 1.97 \\
VCO & 3.56 & 3.47 \\
Minyak Jarak & 4.74 & 4.63 \\
Penoxyetanol & 1.01 & 0.98 \\
Setil Alkohol & 2.13 & 2.08 \\
Arang Aktif & 0 & 2.32 \\
\hline
\end{tabular}

Tabel 3. Rekapitulasi Hasil Pengujian

Table 3. Recapitulation of Test Results

\begin{tabular}{lcccc}
\hline \multicolumn{1}{c}{ Parameter } & \multicolumn{2}{c}{ Sampel } & Syarat SNI & $\begin{array}{c}\text { Sesuai / Tdk } \\
\text { Sesuai }\end{array}$ \\
\hline & SB & SA & & \\
\hline Organoleptik & 6 & 6 & SNI 06-4085-1996, yaitu & Sesuai \\
pH & 9,46 & 9,44 & berkisar 8 - 11 & Sesuai \\
& & & - & Sesuai \\
Logam Hg* & not detected & not detected & - & Sesuai \\
Viskosi tas & 702 & 424 & - & S \\
Stabilitas Busa & $27 \%$ & $80 \%$ & & \\
\hline
\end{tabular}

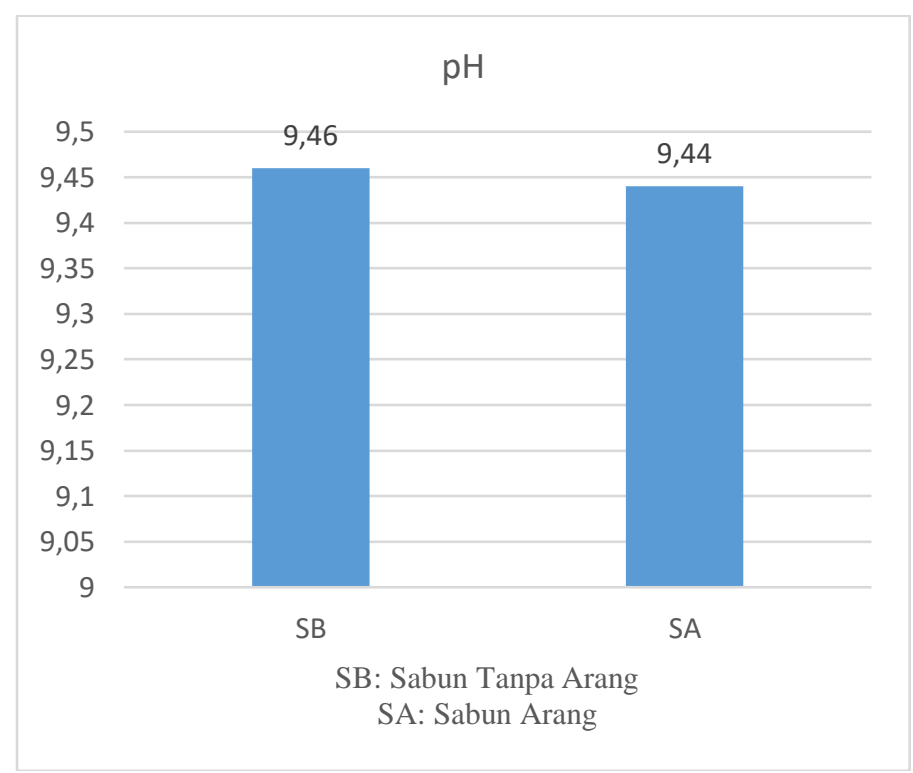

Gambar 1. Nilai pH dengan Penambahan dan Tanpa Penambahan Arang Aktif Figure 1. $\mathrm{pH}$ with Addition and without Addition of Active Charcoal 
Tabel 4. Kandungan Merkuri pada Sabun Mandi Cair Table 4. Mercury Content in Shower Soap

\begin{tabular}{llll}
\hline Parameter & Unit & Result & Limit of Detection \\
\hline $\mathbf{H g}$ & $\mathrm{mg} / \mathrm{kg}$ & Not detected & 0,02 \\
\hline
\end{tabular}

Hasil analisis menunjukkan bahwa viskositas yang dihasilkan sabun mandi cair dengan penambahan arang aktif (SA) adalah 424 cPs, sedangkan sabun mandi cair dengan tanpa penambahan arang aktif (SB) adalah 702 cPs.

Analisa stabilitas busa bertujuan untuk mengetahui prosentase busa yang masih tersisa dalam jangka waktu tertentu. Hasil uji stabilitas sabun mandi cair menunjukkan bahwa prosentase stabilitas busa yang dihasilkan sabun mandi cair dengan arang aktif (SA) adalah $78,93 \%$, sedangkan sabun mandi cair tanpa arang aktif (SB) adalah $26,67 \%$.

\section{Mutu Sensori}

(1) Kesukaan terhadap warna

Kisaran nilai sensori warna yang diberikan panelis antara 2 (tidak suka) hingga 7 (sangat suka). Hasil analisis yang sudah di rata-rata menunjukkan bahwa kesukaan terhadap warna sabun mandi cair yang dihasilkan dengan arang aktif (SA) adalah 5,85. Sabun mandi cair tanpa arang aktif (SB) tingkat kesukaan terhadap warnanya yaitu 5,96 .

(2) Kesukaan terhadap aroma

Kisaran nilai sensori aroma yang dibarikan panelis antara 2 (tidak suka) hingga 7 (sangat suka). Hasil analisis yang sudah di rata-rata menunjukkan bahwa kesukaan terhadap aroma sabun mandi cair yang dihasilkan dengan arang aktif (SA) adalah 5,46. Sabun mandi cair tanpa arang aktif (SB) tingkat kesukaan terhadap aromanya yaitu 5,69.

(3) Kesukaan terhadap kekentalan

Kisaran nilai sensori kekentalan yang diberikan panelis antara 2 (tidak suka) hingga 7 (sangat suka). Hasil analisis yang sudah di rata-rata menunjukkan bahwa kesukaan terhadap kekentalan sabun mandi cair yang dihasilkan dengan arang aktif (SA) adalah 5,5. Sabun mandi cair tanpa arang aktif (SB) tingkat kesukaan terhadap kekentalannya yaitu 5,42.

(4) Kesukaan terhadap jumlah busa sabun mandi cair

Kisaran nilai sensori jumlah busa yang diberikan panelis berkisar antara 3 (agak tidak suka) hingga 7 (sangat suka). Hasil analisis yang sudah di rata-rata menunjukkan bahwa kesukaan terhadap jumlah busa sabun mandi cair yang dihasilkan dengan arang aktif (SA) adalah 5,58. Sabun mandi cair tanpa arang aktif (SB) tingkat kesukaan terhadap jumlah busa yang dihasilkan yaitu 5,38.

(5) Kesukaan terhadap kesan licin Kisaran nilai sensori jumlah busa yang diberikan panelis berkisar antara 3 (agak tidak suka) hingga 7 (sangat suka). Hasil analisis yang sudah di rata-rata menunjukkan bahwa kesukaan terhadap jumlah busa sabun mandi cair yang dihasilkan dengan arang aktif maupun tanpa arang aktif sama nilainya yaitu adalah 5,88.

(6) Kesukaan terhadap kesan lembut yang ditinggalkan

Kisaran nilai sensori jumlah busa yang diberikan panelis berkisar antara 3 (agak tidak suka) hingga 7 (sangat suka). Hasil analisis yang sudah di rata-rata menunjukkan bahwa kesukaan terhadap kesan lembut yang ditinggalkan sabun mandi cair yang dihasilkan dengan arang aktif (SA) adalah 6,58. Sabun mandi cair tanpa 
panambahan arang aktif (SB) tingkat kesukaan terhadap kesan lembut yang

\section{BAHASAN}

\section{Alur proses Pembuatan}

Proses pembuatan sabun mandi cair rumput laut dengan penambahan arang aktif diawali dengan persiapan pembuatan bubur rumput laut yakni dengan menghaluskan rumput laut Gracilaria sp menggunakan blender. Selanjutnya dilakukan persiapan bahan yakni bahan untuk fase minyak dan bahan untuk fase cair. Bahan untuk fase minyak terdiri dari trietilamina, virgin coconut oil, minyak jarak, penoxyetanol, dan setil alkohol. Adapun bahan pada fase cair meliputi: aquades, asam sitrat, EDTA, sodium klorida, potassium hydroxide, dan gliserin.

Proses berikutnya adalah pemasakan, baik fase minyak maupun fase cair. Setelah kedua bahan dimasak kemudian dilakukan pencampuran serta penambahan arang aktif dan bubur rumput laut yang dilakukan pada suhu yang sama agar terjadi homogenisasi campuran. Jika campuran telah homogen, selanjutnya didinginkan untuk kemudian dilakukan pengemasan.

\section{Pengujian}

Menurut Wasitaatmadja (1997), produk kosmetika yang memiliki nilai $\mathrm{pH}$ yang sangat tinggi atau sangat rendah dapat menambah daya absorpsi pada kulit sehingga mengakibatkan kulit teriritasi. Oleh karena itu produk kosmetika perawatan diri sebaiknya dibuat dengan menyesuaikan $\mathrm{pH}$ kulit. Nilai $\mathrm{pH}$ sabun mandi cair tidak ataupun dengan arang aktif yang dihasilkan telah memenuhi persyaratan mutu SNI 06-4085-1996, yaitu berkisar $8-11$.

Nilai viskositas sabun mandi cair dengan penambahan ataupun tanpa penambahan arang aktif yang dihasilkan telah memenuhi persyaratan umum untuk ditinggalkan yang dihasilkan yaitu 6,5 .

viskositas produk sabun mandi cair yaitu 400-4000 cPs (Williams dan Schmitt, 2002). Hingga saat ini masih belum ada standar nilai yang pasti untuk kestabilan busa itu sendiri. Busa adalah dispersi gas dalam cairan yang distabilkan oleh suatu zat pembusa (surfaktan). Kecepatan pembentukan busa dan stabilitas busa merupakan dua hal penting untuk produk pembersih tubuh. Pada penggunaanya busa berperan dalam proses pembersihan dan melimpahkan wangi sabun pada kulit (Hernani et al., 2010).

\section{SIMPULAN}

1) Formulasi bahan pembuatan sabun mandi cair rumput laut dengan penambahan arang aktif memiliki komposisi TEA dan setil alkohol sebanyak 2,08\%, EDTA, sodium klorida dan penoxyetanol sebanyak $0,98 \%$, gliserin dan VCO sebanyak $3,47 \%$, esensial oil sebanyak $0,58 \%$, bubur sebanyak $23,16 \%$, asam sitrat dan arang aktif sebanyak 2,32\%, aquades sebanyak 50,96\%, $\mathrm{KOH}$ sebanyak $1,97 \%$ dan minyak jarak sebanyak $4,63 \%$.

2) Hasil pengujian mutu yang dilakukan pada sabun mandi cair rumput laut dengan penambahan arang aktif yang meliputi pH sebesar 9,44, tidak ditemukannya logam merkuri, viskositas sebesar $424 \mathrm{cPs}$, stabilitas busa sebesar $78,95 \%$ dan untuk pengujian sensori tingkat kesukaan terhadap warna, aroma, kekentalan, jumlah busa, kesan licin, kesan lembut yang ditinggalkan dengan rata-rata nilai tingkat kesukaan 6 (suka) dari skala 1 sampai dengan 7.

\section{DAFTAR PUSTAKA}

Akhmad, A. (2012). Pengaruh
Temperatur Karbonisasi dan
Konsentrasi Zink Klorida 
$\begin{array}{lrr}(\mathrm{ZnCl}) & \text { Terhadap } & \text { Luas } \\ \text { Permukaan } & \text { Karbon } & \text { Aktif }\end{array}$

Enceng Gondok. Teknik

Material dan Metalurgi.

Surabaya: ITS Press.

Astawan. (2004). Agar-Agar sebagai Pencegah Hipertensi. www. kompas. com. [20 November 2005]

Deiner, F. (2008). Formula Bath Gel bangkuang- Madu. Bogor: Institut Pertanian Bogor Press.

Hernani, Bunasor, T.K., \& Fitriati. 2010. Formula Sabun Transparan Anti Jamur dengan Bahan Aktif Ekstrka Lengkuas (Alpinia galanga L. Swartz). Buletin Penelitian Tanaman Rempah dan Obat, 21(2), 192-205.

Lempang, M. (2014). Pembuatan dan Kegunaan Arang Aktif. Info Teknis EBONI, 11 (2), 65-80.

Rahayu, W. P. (1998). Penuntun Praktikum Penilaian Organoleptik. Bogor: Jurusan Teknologi Pangan dan Gizi, FATETA-IPB.

Salam, R. R. S. (2003). Kualitas Sabun Mandi Cair Dengan Penambahan Madu Ekstrak Polen. [skripsi]. Bogor: Fakultas Peternakan, IPB.

Sharma, A., Yadav, R., Gudha, V., Soni, U. N., \& Patel, J. R. 2016. Formulation and Evaluation Of Herbal Hand Wash. World Journal of Pharmacy and
Pharmaceutical Sciences, 5 (3): 675-683.

Siddiq, N. A. (2015). Kupas Tuntas Arang Aktif. https://wastek.com /2015/06/05/arang-aktif/.

Diakses pada tanggal 6 Maret 2019.

[SNI] Standar Nasional Indonesia. (1996). Sabun Mandi Cair. SNI: 06-4085-1996. Jakarta: Dewan Standarisasi Nasional.

Suhartono. (2000). Manfaat dan Kandungan Biota-biota Laut. Yogyakarta: Kanisius Press.

Suryakusuma, K. (2006). Aplikasi AgarAgar Rumput Laut Gelidium sp. Sebagai Pengental Pada Formulasi Sabun Mandi Cair. Bogor: Jurusan Teknologi Hasil Perikanan Fakultas Perikanan Dan Ilmu Kelautan- IPB.

Wasitaatmadja, S. M. (1997). Penuntun Ilmu Kosmetik Medik. Jakarta: UI-Press.

Williams, D. F., \& Schmitt, W. H. (2002). Kimia dan Teknologi dan Produk-Produk Perawatan Diri. Terjemahan. Bogor: IPB Press.

Yustinah, H. (2011). Absorbsi Minyak Goreng Bekas Menggunakan Arang Aktif dari Sabut Kelapa. (Prosiding Seminar). Jakarta: Jurusan Teknik Kimia, Fakultas Teknik, Universitas Muhammadiyah Jakarta. 